Provided for non-commercial research and education use. Not for reproduction, distribution or commercial use.

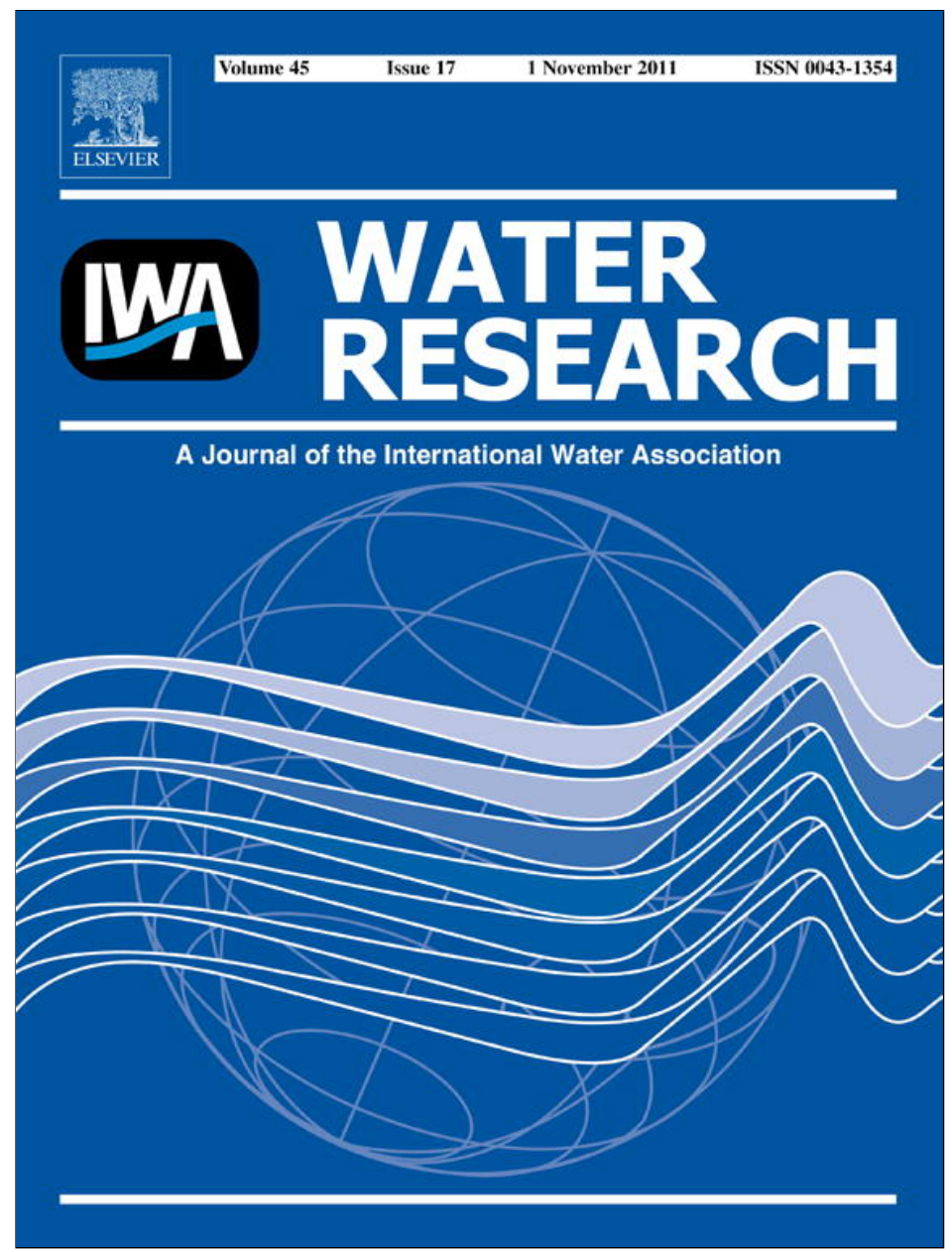

This article appeared in a journal published by Elsevier. The attached copy is furnished to the author for internal non-commercial research and education use, including for instruction at the authors institution and sharing with colleagues.

Other uses, including reproduction and distribution, or selling or licensing copies, or posting to personal, institutional or third party websites are prohibited.

In most cases authors are permitted to post their version of the article (e.g. in Word or Tex form) to their personal website or institutional repository. Authors requiring further information regarding Elsevier's archiving and manuscript policies are encouraged to visit:

http://www.elsevier.com/copyright 


\title{
Nitrification and potential control mechanisms in simulated premises plumbing
}

\author{
Mohammad Shahedur Rahman $^{a, 1}$, Gem Encarnacion ${ }^{a, b}$, Anne K. Camper ${ }^{a, c, *}$ \\ ${ }^{a}$ Center for Biofilm Engineering, Montana State University, 366 EPS Building, Bozeman, MT 59717, USA \\ ${ }^{\mathrm{b}}$ Department of Microbiology, Montana State University, Bozeman, MT 59717, USA \\ ${ }^{\mathrm{c}}$ Department of Civil Engineering, Montana State University, Bozeman, MT 59717, USA
}

\section{A R T I C L E I N F O}

\section{Article history:}

Received 7 February 2011

Received in revised form

19 July 2011

Accepted 7 August 2011

Available online 16 August 2011

\section{Keywords:}

Nitrification

Biofilms

Chlorite

Chloramines

Copper

Plumbing

\begin{abstract}
A B S T R A C T
Indigenous drinking water organisms were used to establish nitrification in glass reactors containing copper or polyvinyl chloride (PVC) surfaces. The reactors were fed soil-derived humics as the organic carbon source and ammonium sulfate as the nitrogen source in biologically treated tap water. Water in the reactors was stagnant for $8 \mathrm{~h}$ and then flowed for 5 min to simulate conditions in household plumbing. Following the establishment of complete nitrification (conversion of ammonia to nitrate) in both reactor types, various inhibitors of nitrification were tested followed by a period where recovery of nitrification was observed. In one PVC reactor, copper was gradually introduced up to $1.3 \mathrm{ppm}$. To ensure that most of the copper was in the ionic form, the $\mathrm{pH}$ of the influent was then gradually lowered to 6.6. No significant change in nitrification was observed in the presence of copper. Chlorite was introduced into copper and PVC reactors at doses increasing from $0.2 \mathrm{ppm}$ to $20 \mathrm{ppm}$. There was limited effect on the PVC system and inhibition in the copper reactor only at $20 \mathrm{ppm}$. Chloramine was tested at chlorine to ammonia ratios ranging from $0.5: 1$ to $5: 1$. Nitrification activity was impacted significantly at a 5:1 ratio and ultimately stopped, with the fastest response being in the copper system. Whenever a control mechanism was tested, there was increased release of copper from the reactors with copper coupons. In all cases, nitrification recovered when inhibitors were removed but the rates of recovery differed depending on the treatment method and coupon surface. ๑) 2011 Elsevier Ltd. All rights reserved.
\end{abstract}

\section{Introduction}

A topic of regulatory and public health concern in drinking water is the creation of potentially carcinogenic disinfection by-products (DBPs) when the water is chlorinated. As an alternative to chlorination, many utilities have shifted to the use of chloramines to reduce the levels of regulated DBPs to meet the Stage 2 Disinfectants/Disinfection By-Product Rule (USEPA, 2000). Although the use of chloramines as a secondary disinfectant can reduce DBPs, there is the chance that increased levels of free ammonia in the distribution system may serve as an energy source for indigenous nitrifying organisms. Proliferation of these organisms can then result in nitrification in the distribution system. Not surprisingly, nitrification is one of the most frequent operational problems encountered by drinking water utilities that use chloramine for secondary disinfection (Skadsen, 1993; Wolfe and Lieu, 2001; Odell et al., 1996; Wilczak et al., 1996; Seidel et al., 2005).

\footnotetext{
* Corresponding author. Center for Biofilm Engineering, Montana State University, 366 EPS Building, Bozeman, MT 59717, USA. Tel.: +1 406994 4906; fax: +1 4069946098.

E-mail address: anne_c@biofilm.montana.edu (A.K. Camper).

${ }^{1}$ Current address: Anderson Civil Consultants Nanaimo, BC V9R 2T5, Canada. 0043-1354/\$ - see front matter (c) 2011 Elsevier Ltd. All rights reserved.
} doi:10.1016/j.watres.2011.08.009 
Nitrification is a microbial process by which reduced nitrogen compounds (primarily ammonia) are sequentially oxidized to nitrite and nitrate. This process can have a detrimental impact on water quality. Due to nitrification, chloramine residual, $\mathrm{pH}$, alkalinity and dissolved oxygen of water decrease. As nitrification can cause a decrease in $\mathrm{pH}$, some utilities may be susceptible to elevated levels of soluble metal contaminants such as lead (Zhang et al., 2009), leading to Lead and Copper Rule (LCR) violations. Nitrification can also cause biological instability through production of soluble microbial products which may support the growth of heterotrophic bacteria in low nutrient environments (Rittmann et al., 1994).

Studies on nitrification in drinking water have mostly been done in distribution mains or at the treatment plant level and studies on premises plumbing are lacking. Premises plumbing not only has higher surface to volume ratios but also has about 10 times more length than water mains (NRC, 2006). In addition, it stands to reason that favorable conditions for nitrification such as low or no disinfectant, long water age and warmer temperatures exist in premises plumbing. This gap in knowledge led to investigations on possible control for nitrification in premises plumbing. The studies took place in laboratory reactors designed to simulate the surface area to volume ratios, flow conditions, and water quality that may be encountered in these systems. Ammonia concentrations chosen represented a worst case scenario where all the chloramine added at the regulatory limit (4 ppm) had decayed to release ammonia. Two commonly utilized premises plumbing materials, copper and polyvinyl chloride (PVC), were used. Copper is the most widely used metal for household plumbing systems and more than $90 \%$ of domestic plumbing material in the US is made of copper (Oskarsson and Norrgren, 1998) while PVC pipes are also a very common plumbing material (NSF, 2008).

Three separate strategies based on realistic approaches for drinking water systems were evaluated. First, the inhibitory effect of copper was examined by (1) comparing nitrification in PVC vs copper reactors and (2) by introducing known amounts of copper (gradually increasing concentration) into a nitrifying reactor with PVC coupons. Previous work has shown that nitrification in pure cultures is either enhanced or inhibited by copper, depending on its concentration. Loveless and Painter (1968) found that $0.005-0.03 \mathrm{ppm}$ of $\mathrm{Cu}^{+2}$ stimulated the growth of the ammonia oxidizer Nitrosomonas while Skinner and Walker (1961) observed enhanced growth at higher concentrations of 0.1-0.5 ppm copper. However, these higher concentrations were found to be inhibitory by Loveless and Painter (1968). Zhang and Edwards (2005) observed slight inhibition of nitrification for pure cultures in the presence of 5 ppb copper while 25 ppb copper had a slightly stimulatory effect. In the same study, a much higher concentration of $500 \mathrm{ppb}$ copper significantly inhibited nitrification. Zhang and Edwards (2010) also reported inhibition of nitrification at copper levels greater than $100 \mu \mathrm{g} / \mathrm{L}$. In cases where there is free ammonia, copper-ammonia complexes such as [Cu $\left.\left(\mathrm{NH}_{3}\right)_{\mathrm{X}}^{2+}\right]$, (Sato et al., 1988) and cupric tetraamine $\left[\mathrm{Cu}\left(\mathrm{NH}_{3}\right)_{4}^{+2}\right]$ (Lee et al., 1997) may also be responsible for inhibition of nitrifiers. It is also important to know the form in which the copper exists because $\mathrm{Cu}^{+2}$ ions are believed to be responsible for the inhibition of nitrifying bacteria (Braam and Klapwijk,
1981; $\mathrm{Hu}$ et al., 2003). Cupric ions in the vicinity of the cell membrane may cause damage by depolarization and impairment of receptors or transporter molecules (Alt et al., 1990), and may bind proteins and block the function of proteins in the exoploymeric substance (EPS) of the bacteria (Geesey and Jang, 1989). Ion speciation can be controlled by the $\mathrm{pH}$ (Braam and Klapwijk, 1981; Edwards et al., 1996), and this was considered as part of the experimental design.

A second set of experiments was done to determine the impact of chlorite on nitrification. The use of chlorite as a control mechanism for nitrification has been proposed for full scale distribution systems and storage tanks. Hynes and Knowles (1983) showed that chlorite interfered with the first step of nitrification, specifically in the oxidation of ammonia to nitrite by Nitrosomonas europea. Several studies in both laboratory and full scale drinking water distribution systems have been conducted to investigate the effect of chlorite on nitrification. McGuire et al. (1999) found that low levels (0.2 ppm) of chlorite caused a significant reduction in the culturability of ammonia oxidizing bacteria (AOB). In the same study, the experience of the Gulf Coast (Texas) Water Authority (GCWA) which uses chlorine dioxide as the primary disinfectant and chloramine as the secondary disinfectant was reported. Chlorite was detected in their distribution system in the range of $0.25-0.35 \mathrm{ppm}$ and although the conditions were conducive to nitrification, it did not occur suggesting the inhibitory effect of chlorite to nitrification. In another study conducted in plug flow reactors in Tucson AZ, continuous feed of chlorite at concentrations as low as $0.1 \mathrm{ppm}$ was found to prevent nitrification (McGuire et al., 1999). Chlorite was also used to prevent nitrification in parts of the Glendale, CA distribution system (McGuire et al., 2009). Interestingly, chlorite has been found to be ineffective in controlling nitrification in other studies. McGuire et al. (1999) reported a nitrification episode in the Corpus Christi Texas distribution system that continued even after dosing with chlorite. Similarly, Karim and LeChevallier (2006) reported the recurrence of nitrification in a pilot system where initially the use of $0.5 \mathrm{ppm}$ chlorite controlled nitrification. In another study the presence of chlorite in water reservoirs prevented the onset of nitrification, but once nitrification started, introducing chlorite was not effective and a $0.2 \mathrm{ppm}$ dose of chlorite in a nitrifying reservoir inhibited nitrification for only two weeks (McGuire et al., 2006). To investigate the impact of chlorite on nitrification in the simulated premises plumbing system, doses were incrementally increased from 0.2 to $20 \mathrm{ppm}$.

A third potential control mechanism was maintaining a chloramine disinfectant residual within the plumbing system. Chloramine, although considered as a weaker disinfectant than chlorine for suspended cells, is thought to be more effective for disinfecting biofilms (LeChevallier et al., 1988; Wahman et al., 2009), and since most nitrifying bacteria are present as biofilms rather than planktonic cells in both natural and engineered systems (Schramm et al., 1996; Okabe et al., 2005; Kindaichi et al., 2006), the use of chloramine was also examined. In an actual water distribution system, it may be possible to either distribute water with a stable residual or recreate chloramine through booster chlorination. To investigate this experimentally, chlorine was applied to attain different chlorine to ammonia ratios. 
All of these experiments took place in reactors that had been undergoing complete nitrification (conversion of ammonia to nitrate) for one year. Importantly, the reactors had undefined mixed population biofilms originating from Bozeman tap water and were not inoculated with specific nitrifying organisms. The operating conditions were carefully chosen to represent conditions in premises plumbing while allowing for meaningful sampling strategies and control of variables. During each test, effluent copper concentrations were measured to assess the influence of that strategy on copper release. As such, the results provide insights on how indigenous nitrifying biofilm communities respond to potential control strategies and how these strategies influence effluent water quality.

\section{Materials and methods}

\subsection{Reactors}

Domestic plumbing systems were simulated using a modified CDC reactor (Goeres et al., 2005). Modifications included adding parallel coupons to solid rods, adding a base plate, and changing the stir blades to either polyvinyl chloride (PVC) or copper (Fig. 1). The surface area of the coupons, base plate and stir blades was calculated to create the same surface to volume ratio as that of a six foot long $3 / 4$ " diameter domestic plumbing pipe. The PVC or copper was washed with $0.1 \mathrm{~N}$ $\mathrm{NaOH}$ three times prior to use. Volume of the reactors is $120 \mathrm{ml}$.

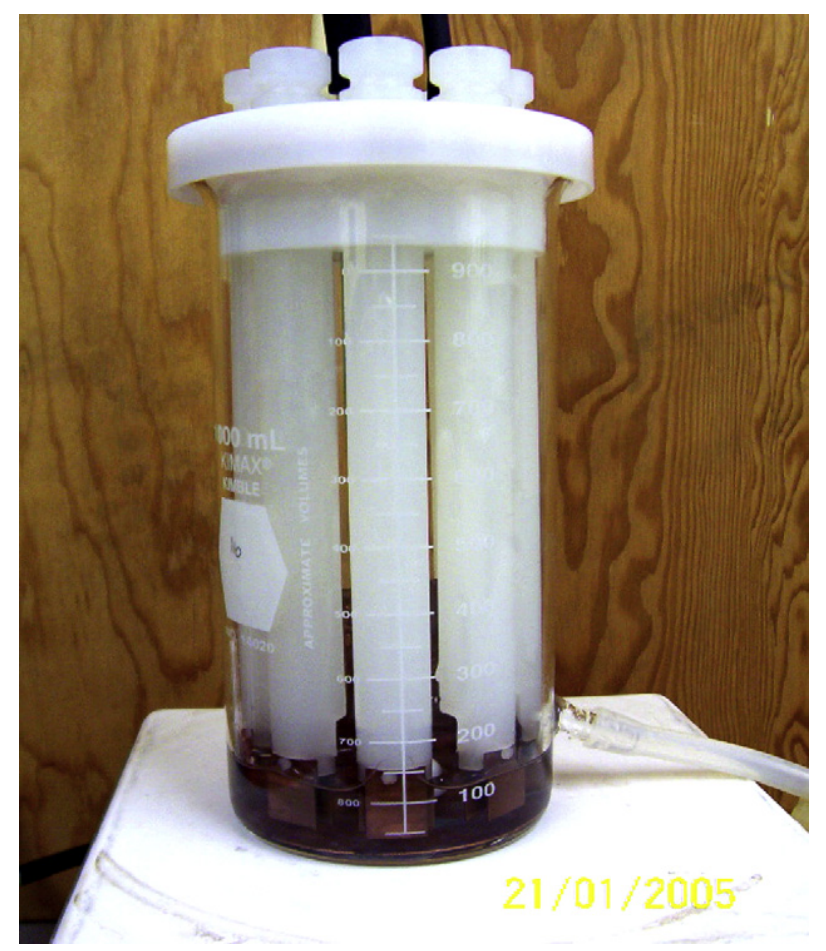

Fig. 1 - Modified CDC reactor showing the paired copper coupons $(1.5 \times 1.7 \mathrm{~cm}$ inside, $1.5 \times 1.3 \mathrm{~cm}$ outside on the rods), base plate (bottom of the reactor) and the blade in the center.

\subsection{Operational scheme}

To simulate periods of stagnation in home plumbing the reactors were flushed with peristaltic pumps with shear created by the stirplate for 5 min followed by $8 \mathrm{~h}$ stagnation periods. The feed pumps and stirplates were controlled by timers that were offset by $1 \mathrm{~min}$ with the stirplate starting before the pumps. At the end of 5 min the stirplates stopped, followed by the pumps. The stirplates were set to create a rotational speed of the blade of $300 \mathrm{rpm}$, which was approximately equivalent to a velocity of $3 \mathrm{ft} / \mathrm{s}$ in the bulk water. The cycle was repeated three times per day.

Two sets (four reactors each) of modified CDC reactors equipped with two different types of coupons (PVC and copper) were used in this investigation. All reactors had been in operation for more than one year and showed signs of stable, complete nitrification as measured by conversion of ammonia to nitrate.

\subsection{Stock/feed solution preparation}

All reactors were fed with a combination of mineral amended reverse osmosis (RO) water, biologically treated Bozeman tap water, and a humic substances organic feed. The RO water was amended to create an alkalinity of $35 \mathrm{mg} / \mathrm{L}$ as $\mathrm{CaCO}_{3}$ and a stable $\mathrm{pH}$ of 8.15. Constituents of the $\mathrm{RO}$ water + mineral feed were $\mathrm{MgSO}_{4}(39.6 \mathrm{mg} / \mathrm{L}), \mathrm{NaHCO}_{3}(59.6 \mathrm{mg} / \mathrm{L}), \mathrm{CaSO}_{4} \cdot 2 \mathrm{H}_{2} \mathrm{O}$ $(25 \mathrm{mg} / \mathrm{L}), \mathrm{Al}_{2}\left(\mathrm{SO}_{4}\right) \cdot 18 \mathrm{H}_{2} \mathrm{O}(0.62 \mathrm{mg} / \mathrm{L}), \mathrm{CaCl}_{2} \cdot 2 \mathrm{H}_{2} \mathrm{O}(20.80 \mathrm{mg} /$ $\mathrm{L})$, and $\mathrm{Na}_{2} \mathrm{SiO}_{3} \cdot 9 \mathrm{H}_{2} \mathrm{O}(26 \mathrm{mg} / \mathrm{L})$. Ammonium sulfate was added to provide a final concentration in the reactor of $0.71 \mathrm{mg} / \mathrm{L}$ as N. Biologically treated water provided as a separate, parallel influent. It was created by flowing Bozeman tap water (surface water source, no background ammonia, chlorinated) through a granular activated carbon column followed by flow through a biologically active carbon column to provide a continuous inoculum of indigenous organisms $\left(10^{4} \mathrm{CFU} / \mathrm{ml}\right.$ of heterotrophic plate count (HPC)) that was the only source of microorganisms to the reactors. This water also contained sufficient background phosphate for microbial growth at the organic carbon level used. Organic carbon was supplied to the reactors in a third, separate influent in the form of soil-derived humic substances. 50 grams of Elliot silt loam soil (International Humic Substances Society) was added to $500 \mathrm{ml}$ of $0.1 \mathrm{~N}$ $\mathrm{NaOH}$ and mixed for $48 \mathrm{~h}$. This solution was centrifuged at $10,000 \times \mathrm{g}$ for $20 \mathrm{~min}$. The supernatant was collected in carbon free glassware (baked at $390^{\circ} \mathrm{C}$ for $5 \mathrm{~h}$ ) and stored at $4{ }^{\circ} \mathrm{C}$ in the dark. Total organic carbon content of the humics was measured using a Dohrman DC- $80^{\circledR}$ and subsequently diluted to the appropriate concentration using the RO water feeding the reactors to provide a concentration in the reactors of $4 \mathrm{mg} /$ $\mathrm{L}$ as dissolved organic carbon. The RO water/biologically treated Bozeman tap water/organic carbon feed ratio was 50:5:1.

Other amendments and modifications of the influent feed are described below for each set of specific experiments.

\subsection{Sampling}

Water was collected from the reactors at the end of the $8 \mathrm{~h}$ stagnation period three times weekly. Samples were analyzed 
for ammonia, nitrate, and nitrite. Weekly samples were analyzed for heterotrophic plate counts, ammonia oxidizing bacteria, and nitrite oxidizing bacteria.

Free $\mathrm{NH}_{3}-\mathrm{N}$ was measured using a $\mathrm{HACH} 2000$ spectrophotometer using the salicylate method ( $\mathrm{HACH}$ method 10023) at $655 \mathrm{~nm}$ immediately after the samples were collected. Nitrite was analyzed using a HACH 2000 spectrophotometer and the diazotization method. Reaction of nitrite with sulfanilic acid and forms an intermediate diazonium salt that couples with chromotropic acid to produce a pink colored complex measured at $507 \mathrm{~nm}$. Nitrate in filtered samples (0.2 $\mathrm{mm}$ pore size polyethersulfone) was measured using a Dionex ${ }^{\circledR}$ ion chromatography system with a CD20 conductivity detector and GP40 gradient pump unit. An AS4A column and DS3 detection stabilizer was also used in this method. The Dione ${ }^{\circledR}$ ion chromatography system was calibrated using five sodium nitrate standards $\left(1,0.5,0.2,0.1,0 \mathrm{ppm}\right.$ of $\left.\mathrm{NO}_{3}-\mathrm{N}\right)$. To minimize experimental error, after every seven measurements a standard solution of nitrate was measured to check the accuracy of the measurement. If the obtained measurement of the standard was outside $90-110 \%$ of the standard value then the calibration was repeated and sample was measured again (Standard Methods, 1995).

Heterotrophic plate counts were done according to Standard Methods (1995) 9215A using R2A agar plates. Plates were incubated at $20^{\circ} \mathrm{C}$ for 7 days, and then the number of colonies in the plates was counted using a Quebec colony counter. For the chloramine experiments, the disinfectant was neutralized with sodium thiosulfate prior to dilution and plating.

Ammonia oxidizing bacteria (AOB) and nitrite oxidizing bacteria (NOB) populations were enumerated using the most probable number (MPN) technique (Rowe et al., 1977) using Costar $^{\circledR}$ Clear-Bottom 96 well microtiter plates. The mineral medium used for AOB contained per liter: $\left(\mathrm{NH}_{4}\right)_{2} \mathrm{SO}_{4}, 330 \mathrm{mg}$; $\mathrm{KH}_{2} \mathrm{PO}_{4}, 100 \mathrm{mg} ; \mathrm{MgSO}_{4} \cdot 7 \mathrm{H}_{2} \mathrm{O} 40 \mathrm{mg} ; \mathrm{CaCl}_{2}, 15 \mathrm{mg}$ and $1 \mathrm{ml}$ of a trace-element solution. The trace-element solution contained per liter: $\mathrm{Na}_{2} \mathrm{EDTA}, 4292 \mathrm{mg} ; \mathrm{FeCl}_{2} \cdot 4 \mathrm{H}_{2} \mathrm{O}, 1988 \mathrm{mg}$; $\mathrm{MnCl}_{2} \cdot \mathrm{H}_{2} \mathrm{O}, 99 \mathrm{mg} ; \mathrm{NiCl}_{2} \cdot 6 \mathrm{H}_{2} \mathrm{O}, 24 \mathrm{mg} ; \mathrm{CoCl}_{2} \cdot 6 \mathrm{H}_{2} \mathrm{O}, 24 \mathrm{mg}$; $\mathrm{CuCl}_{2} \cdot 2 \mathrm{H}_{2} \mathrm{O}, 17 \mathrm{mg} ; \mathrm{ZnCl}_{2}, 68 \mathrm{mg} ; \mathrm{Na}_{2} \mathrm{MoO}_{4} \cdot 2 \mathrm{H}_{2} \mathrm{O}, 24 \mathrm{mg}$ and $\mathrm{H}_{3} \mathrm{BO}_{3}, 62 \mathrm{mg}$. Bromothymol blue ( $5 \mathrm{ml} / \mathrm{L}$ of $0.04 \%$ solution in water) was added as a $\mathrm{pH}$ indicator. The $\mathrm{pH}$ was adjusted to 8 using $1 \mathrm{M} \mathrm{NaOH}$ before autoclaving at $110^{\circ} \mathrm{C}$ for $15 \mathrm{~min}$. The NOB medium had the same composition except that it did not contain $\left(\mathrm{NH}_{4}\right) \mathrm{SO}_{4}$ and bromothymol blue, and was supplemented with $34.5 \mathrm{mg} / \mathrm{L} \mathrm{NaNO}_{2}$. The $\mathrm{pH}$ was adjusted to 6.5 with $1 \mathrm{M} \mathrm{NaOH}$ before autoclaving at $110{ }^{\circ} \mathrm{C}$ for $15 \mathrm{~min}$. After inoculation the microtiter plates were sealed with polyester tape to prevent evaporation and incubated for nine weeks at $20^{\circ} \mathrm{C}$ in the dark. After the incubation period AOB and NOB presence was determined by detecting nitrite and nitrate in the medium by adding $40 \mu \mathrm{l}$ of $0.2 \%$ diphenylamine in $\mathrm{H}_{2} \mathrm{SO}_{4}$ in the well. The absorbance of the blue color was measured at $630 \mathrm{~nm}$ with a microplate reader (EL808 ultra microplate reader BioTek instruments ${ }^{\circledR}$ ). The blue color indicated nitrite or nitrate had formed and the well was scored as positive. Griess Ilosvay reagent (Alexander and Clark, 1965) was used to detect nitrite. A red color was produced within $5 \mathrm{~min}$ and absorbance measured after $5 \mathrm{~min}$ at $540 \mathrm{~nm}$ with the microplate reader. If nitrite in the well was detected it was scored as negative for NOB. The difference between the two measurements then allowed for differentiation between AOB and NOB. The MPNs were calculated according to Rowe et al. (1977).

Biofilm samples were collected at the end of each experiment's test period prior to the recovery phase. One coupon was removed from the reactor and placed in a glass tray (baked at $390{ }^{\circ} \mathrm{C}$ for $5 \mathrm{~h}$ ) containing the autoclaved RO water. The coupon was then scraped using an autoclaved rubber policeman inside a laminar flow hood. The biomass with water was poured in a sterilized $50 \mathrm{ml}$ Falcon ${ }^{\circledR}$ tube, which was then homogenized with a homogenizer (Biohomogenizer ${ }^{\circledR}$ Model M133/12810, ESGE ${ }^{\circledR}$ ) for 30 s. From the homogenized biomass, samples were taken for MPN and HPC analysis.

\subsection{Statistical analysis}

Paired t-test analysis was done using Microsoft Excel on the data to see if there are significant differences between two treatments. The level of significance for all tests was $\alpha=0.05$.

\subsection{Experimental approach}

\subsubsection{Effect of copper ion on nitrification}

To test the effect of copper on nitrification, copper in the form of $\mathrm{CuSO}_{4}$ was added to the influent of one nitrifying PVC reactor. Initially $15 \mathrm{ppb}$ copper was continually dosed and incrementally raised to $1.3 \mathrm{ppm}$, which is the action limit for copper according to the Lead and Copper Rule. Each concentration of copper was maintained for two weeks. Another PVC reactor was used as the control where no copper was added. Because nitrification is presumed to be more affected by free copper $\left(\mathrm{Cu}^{+2}\right)$ (Braam and Klapwijk, 1981), and the amount of $\mathrm{Cu}^{+2}$ in solution is a function of $\mathrm{pH}$, the $\mathrm{pH}$ of the influent with 1.3 ppm of copper was then reduced gradually from 8.15 to 6.6 by 0.3 units every two weeks. Another PVC reactor with the influent at the same $\mathrm{pH}$ but with no copper was used a control.

When copper was added to the PVC reactor at lower concentrations (less than $400 \mathrm{ppm}$ ) an ICPMS (inductively coupled plasma mass spectrometer) was used to measure the copper. At higher concentrations a HACH 2000 spectrophotometer (method 8506,560 nm wavelength) was used. Both total and dissolved copper in the effluent water were measured. Dissolved copper is operationally defined as the portion of the copper which passes through a $0.45 \mu \mathrm{m}$ pore size syringe filter. In the presence of colloidal species that can pass through the filter, the method represents an upper bound to truly soluble copper. When the $\mathrm{pH}$ was adjusted, a copper ion selective electrode (Cu-ISE), (Orion cupric electrode, model, 94-29, Boston, MA) was used to measure the free copper $\left(\mathrm{Cu}^{+2}\right)$ in the water. The electrode was calibrated using standard cupric ion solutions according to manufacturer's direction before measuring the sample. Cupric ion at $1.3 \mathrm{ppm}$ total copper and pH 6.6 was measured and was found to be in the $0.90 \pm 0.10 \mathrm{ppm}$ range.

\subsubsection{Effect of chlorite on nitrification}

Laboratory grade sodium chlorite was added to the influent of one PVC and one copper reactor. Initially $0.2 \mathrm{ppm}$ of chlorite was added and gradually increased to $2.0 \mathrm{ppm}$ and then 
a shock load of 20 ppm of chlorite was dosed. Each concentration of chlorite was tested for two weeks. Chlorite was measured by a modification (McGuire et al., 1999) of the US Environmental Protection Agency (USEPA, 1993) method 300 with the Dionex ${ }^{\circledR}$ ion chromatography system described above equipped with an AS9 column and $100 \mu$ l sampling loop. Chlorite was then discontinued and the recovery of nitrification in both the PVC and copper system was observed. Copper concentrations in the copper reactor effluent were also monitored.

\subsubsection{Effect of chloramine on nitrification}

To represent different scenarios that can occur in a distribution system due to chloramine decay, different amounts of chlorine were added in the ammonia-containing RO water influent of two nitrifying copper and PVC reactors. The added sodium hypochlorite formed chloramine with the ammonia in the influent at different chlorine to ammonia ratios. Initially a $0.5: 1$ ratio was applied and gradually raised to $5: 1$. Both free and total chlorine were measured using a Lamotte DC1100 ${ }^{\circledR}$ colorimeter with the DPD colorimetric method (Standard Methods, 1995, method 4500-Cl). At the beginning of the measurement phosphate buffer was added to the sample to maintain a pH between 6.2 and 6.5. Dissolved and total copper in the copper reactor effluents were also measured.

At the end of chloramine exposure, chlorine was discontinued and recovery of nitrification in PVC and copper reactors was compared.

\section{Results}

All experiments were done in reactors where stable, complete nitrification (conversion of ammonia to nitrate) had been occurring for one year. Before initiation of the experiments, there was no difference in ammonia conversion between PVC and copper, and there was good reproducibility in effluent water quality between pairs of reactors with the same coupon materials (data not shown). All testing consisted of a phase where the reactors were exposed to a stepwise change in water quality (addition of copper/change of $\mathrm{pH}$, addition of chlorite, or increase in chlorine to ammonia ratio) and compared to a control reactor with stable influent water quality followed by a recovery period where complete nitrification was again established. As such, the data demonstrated the efficacy of the treatment method in addition to the robustness of the nitrification process.

\subsection{Effect of copper on nitrification}

To eliminate the influence of the copper substratum on the results, these experiments were conducted with copper ion added to a PVC reactor. Copper doses were incrementally increased from 15 to $1300 \mathrm{ppb}$. At the lower copper doses there was little difference in $\mathrm{NH}_{3}$ utilization measured by percent disappearance of influent to effluent concentrations in the effluent. At higher copper doses (i.e., 600-1300 ppb) intermittent small decreases in $\mathrm{NH}_{3}$ utilization were observed. Overall, there was no statistically significant difference in the effluent ammonia concentrations of the copper reactor compared to the control until $600 \mathrm{ppb}$ was reached. After $600 \mathrm{ppb}$ added copper, the difference was significant $(p<0.05)$ but actual measurements differed by a maximum of only $0.05 \mathrm{mg} / \mathrm{L} \mathrm{NH}_{3}-\mathrm{N}$ ( $n=6$ for each copper dose). A similar trend was seen with nitrate measurements; there were very small differences with a maximum variation of $0.04 \mathrm{mg} / \mathrm{L} \mathrm{NO}_{3}-\mathrm{N}$ between the control and copper dosed systems. After the highest copper dose was reached, and to ensure all copper was as $\mathrm{Cu}^{+2}$, the $\mathrm{pH}$ of the reactor was gradually lowered to 6.6. Another PVC reactor without copper where the $\mathrm{pH}$ was also adjusted was used as a control. There were statistically significant differences in effluent ammonia and nitrate levels at all $\mathrm{pH}$ values (7.8-6.6 at 0.3 increments) but the actual amounts were no more than $0.04 \mathrm{mg} / \mathrm{L} \mathrm{NH}_{3}-\mathrm{N}$ or $\mathrm{NO}_{3}-\mathrm{N}$. In all cases, there was no more than $0.26 \mathrm{mg} / \mathrm{L} \mathrm{NH}_{3}-\mathrm{N}$ in the control or copper exposed reactor effluents (range 0.16-0.26) and $\mathrm{NO}_{3}-\mathrm{N}$ ranged from 0.65 to $0.43 \mathrm{mg} / \mathrm{L}$. Only trace amounts of nitrite were measured (data not shown).

There were no significant differences in AOB or NOB MPN counts in the reactor effluents from the copper vs control reactors. Values ranged from 7 to $35 \mathrm{MPN} / \mathrm{ml}$ for $\mathrm{AOB}$ and from 4 to $41 \mathrm{MPN} / \mathrm{ml}$ for NOB. These results are reported because utilities will typically only measure bulk water nitrifier numbers since biofilm interrogation is not feasible. Similarly, there were no differences in the HPC values, with the range from $4 \times 10^{4}$ to $6 \times 10^{5}$ per $\mathrm{ml}$. Increasing copper doses were not statistically correlated with MPN or HPC values.

\subsection{Effect of chlorite on nitrification}

Because chlorite has been used in full scale distribution systems to control nitrification with varying effect, this chemical was added in increasing doses $(0.2-20 \mathrm{ppm})$ to nitrifying PVC and copper reactors. Reactors that did not receive chlorite were maintained as controls. As seen in Fig. 2, low range chlorite (i.e., $0.2-2 \mathrm{ppm}$ ) did not affect nitrification in the PVC reactor. When the dose was increased to $20 \mathrm{ppm}$ the PVC reactor was slightly affected as it temporarily had lower $\mathrm{NH}_{3}-\mathrm{N}$ utilization, but even in the presence of chlorite, complete ammonia loss rebounded. The temporary decreases in $\mathrm{NH}_{3}-\mathrm{N}$ utilization may have been the result of detaching biomass, adaptation to the chlorite, or other unknown factors.

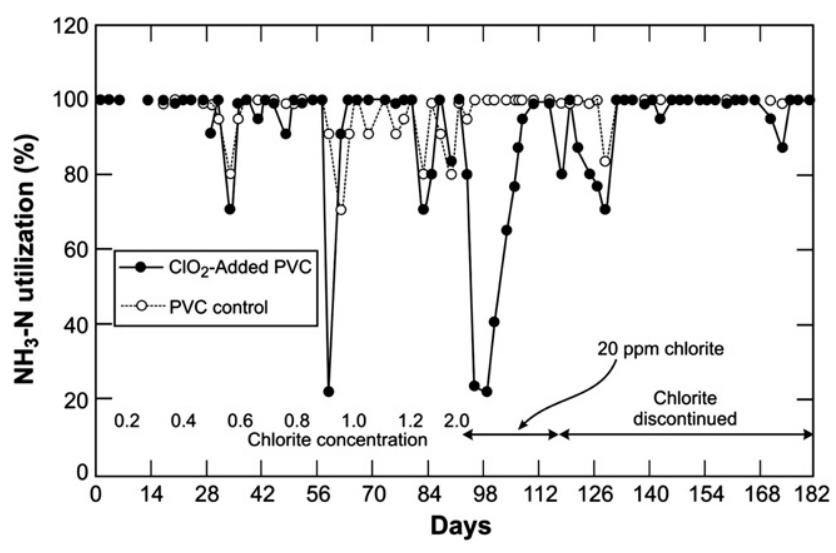

Fig. $2-\mathrm{NH}_{3}-\mathrm{N}$ utilization (\%) in bulk water for chlorite dosed and control PVC reactors. 
The copper reactor was relatively unaffected by lower chlorite doses, but at $20 \mathrm{ppm}$ chlorite, $\mathrm{NH}_{3}-\mathrm{N}$ utilization dropped to zero (Fig. 3). After chlorite was discontinued it took almost two months to re-establish complete nitrification.

The bulk water $\mathrm{NO}_{2}-\mathrm{N}$ and $\mathrm{NO}_{3}-\mathrm{N}$ as percentages of the added $\mathrm{NH}_{3}-\mathrm{N}$ were calculated. For the both reactors, chlorite at the low range $(0.2-2.0 \mathrm{ppm})$ did not significantly affect the $\mathrm{NO}_{2}-\mathrm{N}$ percentage. At 20 ppm chlorite, $\mathrm{NO}_{2}-\mathrm{N}$ percentage increased noticeably to about $1-3 \%$ of the added ammonia in both systems, but the magnitude of this change was only in the ppb range. In the case of $\mathrm{NO}_{3}-\mathrm{N}$, the percent of ammonia converted decreased from near $100 \%-60 \%$ in the PVC reactor the day that the chlorite was increased to $20 \mathrm{ppm}$ and rebounded to the original level of near $100 \%$ within 10 days even when this level of chlorite was maintained. In the case of the copper reactor, the percent conversion dropped to less than $5 \%$ after a week of exposure to $20 \mathrm{ppm}$ chlorite and did not rebound for almost two months.

Effluent total and dissolved copper concentrations in chlorite added and control copper were also measured. The $95 \%$ confidence interval for total and dissolved copper for the chlorite dosed reactor $(0.8 \pm 0.04$ and $0.69 \pm 0.03 \mathrm{ppm})$ was higher than that for control reactor $(0.71 \pm 0.02$ and $0.63 \pm 0.02 \mathrm{ppm})$. A paired t-test for both effluent total and dissolved copper was averaged for chlorite concentrations from 0.1 to $2 \mathrm{ppm}$ and for $20 \mathrm{ppm}$. In all cases, there was significantly more total and dissolved copper in reactors that had received chlorite.

The MPN values for $\mathrm{AOB}$ and $\mathrm{NOB}$ were comparable to those found in the previous copper experiment. The only difference was that at $20 \mathrm{ppm}$ chlorite, no NOB were found in the effluent of both the PVC and copper reactors. HPC values were unaffected and similar to those in the previous copper experiment.

\subsection{Effect of chloramine on nitrification}

The effect of chloramine on nitrification was investigated by gradually increasing the amount of free chlorine fed to the influent of nitrifying PVC and copper reactors. Initially chlorine was added at $0.5: 1$ chlorine to ammonia ratio and gradually raised to a 5:1 ratio, with a total/combined chloramine

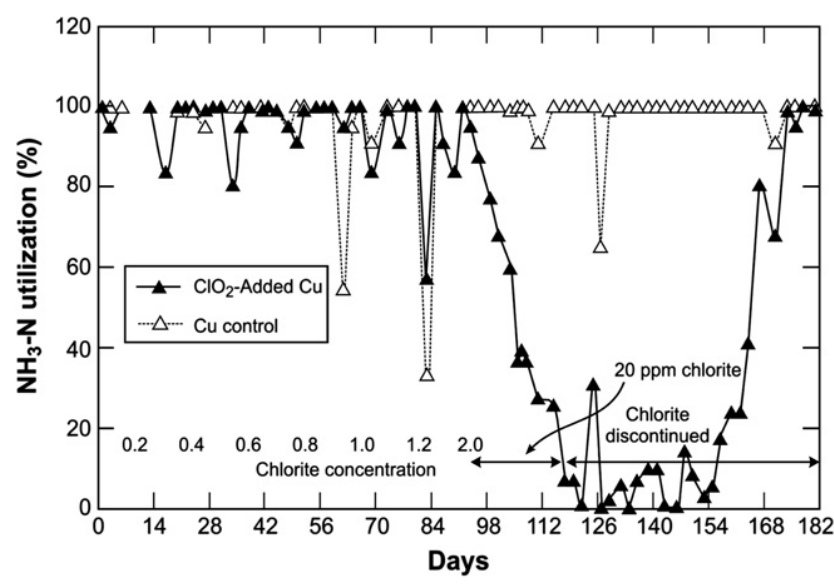

Fig. $3-\mathrm{NH}_{3}-\mathrm{N}$ utilization (\%) in bulk water for chlorite dosed and control copper reactors. dose of $3.55 \mathrm{mg} / \mathrm{L}$. $\mathrm{NH}_{3}$ utilization in the chloramine dosed PVC, copper and control reactors are shown in Fig. 4. Bulk $\mathrm{NH}_{3}-\mathrm{N}$ utilization decreased significantly only at the 5:1 chlorine to ammonia ratio, with occasional decreases at the lower ratios. Note that the $5: 1$ ratio was maintained for two months and there was a long period of acclimation where the ammonia utilization gradually declined. Even at the 5:1 ratio after two months of exposure, the copper reactor continued to utilize around $20 \%$ of the ammonia. When chloramine was discontinued, the copper reactor regained full nitrification after three weeks. In contrast, the PVC reactor ceased ammonia utilization at the higher ratio and it required approximately six weeks to recover its nitrifying ability.

The percent conversion of ammonia in the influent to $\mathrm{NO}_{2}-\mathrm{N}$ and $\mathrm{NO}_{3}-\mathrm{N}$ in the reactors after $8 \mathrm{~h}$ of stagnation was calculated for all chlorine to ammonia ratios. Only in the case of the 5:1 ratio in the PVC reactor did the nitrite level initially increase from the detection limit and peaked at two weeks to approximately $1.4 \%$ of the added nitrogen. This level then again decreased to no detectable nitrite. There was no change in nitrite in the copper reactors as a result of increased chlorine to ammonia ratios; it remained at the limit of detection suggesting complete conversion to nitrate. For the copper reactor, the percent of ammonia converted to nitrate dropped one week after attaining the 5:1 ratio to an average of $18 \%$ conversion and it took two weeks to reach an average of $12 \%$ in the PVC reactor. When chlorine addition was terminated, there was a rebound of total conversion of ammonia to nitrate approximately three weeks later for the PVC reactor. This time was considerably longer (seven weeks) for the copper reactor, and corresponds to the complete loss of ammonia (Fig. 4).

Total and dissolved copper concentrations in the effluent of the monochloramine-dosed and control copper reactors were measured at each chlorine to ammonia ratio. The $95 \%$ confidence intervals for total and dissolved copper for the monochloramine-dosed reactor $(0.83 \pm 0.02$ and $0.73 \pm 0.02)$ are higher than that for control reactor $(0.75 \pm 0.02$ and $0.63 \pm 0.01)$. A paired $t$-test showed that the $p$ values for total and dissolved copper were significantly different. It appears that the presence of monochloramine significantly increased the copper concentration in the water.

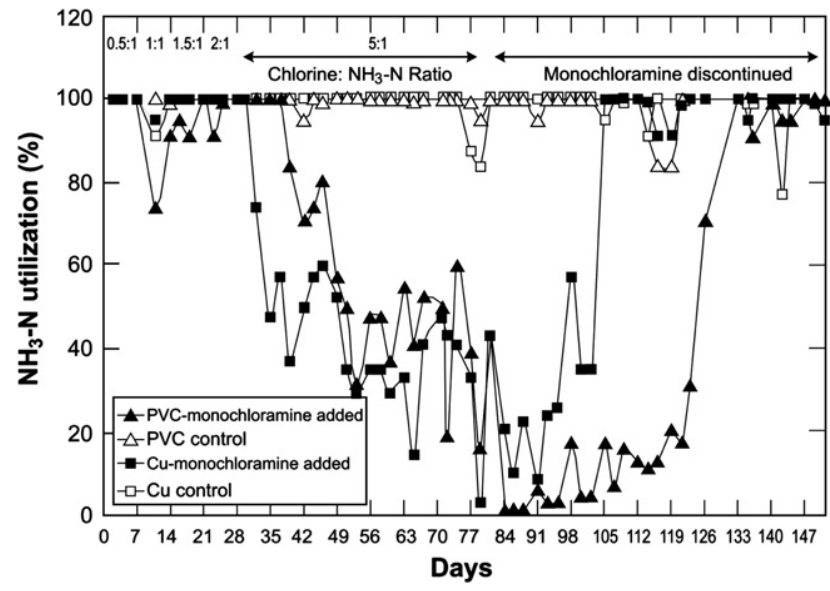

Fig. $4-\mathrm{NH}_{3}-\mathrm{N}$ utilization (\%) in bulk water for chloramine dosed (PVC, copper) and control (PVC, copper) reactors. 
The average MPN value for $A O B$ and NOB in the reactor water are shown in Table 1. In general, there were fewer $A O B$ and NOB in reactors that received chlorine. No NOB were detected in the presence of chloramine at the 5:1 ratio in either reactor which is consistent with the increased level of nitrite that was measured. HPC effluent counts were unaffected and comparable to those of the control reactors that did not receive chlorine (data not shown).

\subsection{Effect of copper, chlorite and chloramine on biofilm cell numbers}

$\mathrm{AOB} / \mathrm{NOB}$ and HPC numbers in the biofilm were determined at the end of each experiment and before the recovery phase (Table 2). AOB/NOB abundance is typically about 3 logs lower than the HPC with the exception of the highest chlorine to ammonia $(5: 1)$ ratio in the copper reactor, where the AOB were present at numbers greater than that of the heterotrophs. No NOB were detected in the copper reactor biofilms at the termination of the chlorite and chloramine experiments. A lack of detection of NOB in the biofilm and the bulk water is consistent with the increased levels of nitrite measured in these reactors.

\section{Discussion}

In this project three different strategies for controlling nitrification in household plumbing were studied. The inhibitory effect of copper, chlorite, and a chloramine residual on nitrification were tested. The impact of each control measure on the release of total and ionic copper from copper coupons into solution was also evaluated. Throughout the experiments in the control reactors, there was total loss of ammonia, no detectable nitrite, and near complete conversion of ammonia to nitrate. This suggests that nitrite was likely formed but converted to nitrate within the $8 \mathrm{~h}$ stagnation period of the experimental system and that complete nitrification was occurring. Complete nitrification is contrary to what has often

Table 1 - Average $(n=2)$ MPN per $\mathrm{ml}$ for ammonia oxidizing bacteria (AOB) and nitrite oxidizing bacteria (NOB) at different $\mathrm{Cl}_{2}$ to $\mathrm{NH}_{3}-\mathrm{N}$ ratios. $\mathrm{ND}=$ none detected.

\begin{tabular}{|c|c|c|c|c|c|}
\hline $\begin{array}{l}\text { Chlorine } \\
\text { to } \mathrm{NH}_{3}-\mathrm{N} \\
\text { ratio }\end{array}$ & & $\begin{array}{l}\mathrm{NH}_{2} \mathrm{Cl} \\
\text { added PVC } \\
\text { reactor }\end{array}$ & $\begin{array}{l}\text { Control } \\
\text { PVC } \\
\text { reactor }\end{array}$ & $\begin{array}{l}\mathrm{NH}_{2} \mathrm{Cl} \\
\text { added } \\
\text { copper } \\
\text { reactor }\end{array}$ & $\begin{array}{l}\text { Control } \\
\text { copper } \\
\text { reactor }\end{array}$ \\
\hline $0.5: 1$ & $\mathrm{AOB}$ & 31 & 37.7 & 10.7 & 38.1 \\
\hline $1.0: 1.0$ & & 27.6 & 31.5 & 10.4 & 14.5 \\
\hline $1.5: 1$ & & 9.7 & 52.2 & 6.9 & 27.6 \\
\hline 2:01 & & 7.2 & 9.5 & 8.7 & 17 \\
\hline 5:01 & & 12.7 & 31.4 & 13.2 & 21.2 \\
\hline $0.5: 1$ & NOB & 48.8 & 59.1 & 106.7 & 30.3 \\
\hline 1.0:1.0 & & 9.7 & 23.3 & 23.5 & 51.5 \\
\hline $1.5: 1$ & & 21 & 351.9 & 28.5 & 170.9 \\
\hline 2:01 & & 8.4 & 793.6 & 10.2 & 61.5 \\
\hline 5:01 & & ND & 310.1 & ND & 48.3 \\
\hline
\end{tabular}

Table 2 - Cell numbers for autotrophic and heterotrophic populations in the biofilm at the end of each experiment. AOB - ammonia oxidizing bacteria, NOB - nitrite oxidizing bacteria, HPC - heterotrophic plate counts. ND $=$ none detected.

\begin{tabular}{lccc} 
& $\begin{array}{c}\mathrm{AOB} \\
\left(\mathrm{MPN} / \mathrm{cm}^{2}\right)\end{array}$ & $\begin{array}{c}\mathrm{NOB} \\
\left(\mathrm{MPN} / \mathrm{cm}^{2}\right)\end{array}$ & $\begin{array}{c}\mathrm{HPC} \\
\left(\mathrm{CFU} / \mathrm{cm}^{2}\right)\end{array}$ \\
\hline Copper added PVC & $5.7 \times 10^{3}$ & $4.4 \times 10^{3}$ & $1.6 \times 10^{6}$ \\
pH Control PVC & $2.8 \times 10^{3}$ & $3.2 \times 10^{3}$ & $7.7 \times 10^{5}$ \\
Chlorite added PVC & $3.5 \times 10^{2}$ & $7.7 \times 10^{1}$ & $1.5 \times 10^{6}$ \\
$\mathrm{NH}_{2} \mathrm{Cl}$ added PVC & $9.2 \times 10^{1}$ & $7.9 \times 10^{2}$ & $1.2 \times 10^{5}$ \\
PVC-control & $2.4 \times 10^{3}$ & $2.8 \times 10^{3}$ & $1.2 \times 10^{6}$ \\
Chlorite added copper & $1.3 \times 10^{1}$ & $\mathrm{ND}$ & $1.8 \times 10^{5}$ \\
$\mathrm{NH}_{2} \mathrm{Cl}$ added copper & $1.4 \times 10^{2}$ & $\mathrm{ND}$ & $9.8 \times 10^{1}$ \\
Copper-control & $1.1 \times 10^{3}$ & $8.0 \times 10^{2}$ & $1.8 \times 10^{5}$ \\
\hline
\end{tabular}

been observed in nitrifying water distribution systems where there is incomplete nitrification, nitrite accumulation, and high nitrite-N concentrations (Wolfe et al., 1988).

\section{1. $\quad$ Added copper}

Copper introduced to the nitrifying PVC reactor did not have a significant effect on ammonia utilization, nor on nitrate concentration in the reactor. The numbers of HPC, AOB and NOB were also unaffected by copper. This observation contradicts the results from other researchers (Skinner and Walker, 1961; Loveless and Painter, 1968; Martin and Richard, 1982; Zhang and Edwards, 2005, 2010), who reported that low ( $5 \mathrm{ppb}-0.56 \mathrm{ppm}$ ) copper concentrations inhibited nitrification. It is possible that inhibition may have occurred if concentrations had been increased to higher levels as those used by Tomlinson et al. (1966) and Meiklejohn (1950). The discrepancy in copper sensitivity between the results of this work and that of others may be because the previous work was done with pure cultures or activated sludge, and the copper tolerance for those biological systems may be much different from the biofilm grown in the reactors used in this project. Another possible explanation is that organic matter contains functional groups (Sarathy and Allen, 2005) that bind metals to form less bioavailable complexes (Loveless and Painter, 1968; Dodge and Theis, 1979; Crecelius et al., 1982) that are therefore less inhibitory (Kim et al., 2006). The humics used in this research may have acted in this capacity although the copper in the reactor water was detected in the ionic form.

Added copper also had no impact on the HPC numbers in the reactors. This is in contrast to the findings of others (Thurman and Gerba, 1989; Artz and Killham, 2002; Kim et al., 2002; Teitzel and Parsek, 2003; Lehtola et al., 2004) who reported that copper has a toxic effect on heterotrophs in drinking water. Again this discrepancy may be due to the difference in experimental conditions and bacterial populations. Another potential explanation is that the reactors used in this study contained intact, natural biofilms that had been present for over a year while other studies used suspended organisms and/or fresh copper surfaces.

Copper toxicity depends on the concentration of cupric ion $\left(\mathrm{Cu}^{+2}\right)$ (Braam and Klapwijk, 1981), and this ionic form 
becomes more abundant at a lower pH (Edwards et al., 1996). Even when the $\mathrm{pH}$ of the reactor was lowered to 6.6 to ensure that the added copper was in the cupric ion form, there was no effect on nitrification or the numbers of AOB, NOB or HPC in the reactor effluent or in the biofilm.

\subsection{Chlorite}

Chlorite was chosen as another potential control mechanism because previous studies by McGuire et al. (1999) showed that chlorite ion $(0.2-1.0 \mathrm{ppm})$ in distribution systems can inhibit nitrification. Results in this project contradict their reports. The PVC reactor was initially impacted only at the unrealistic dose of $20 \mathrm{ppm}$ chlorite but then regained the ability to nitrify in the presence of this concentration. At this high concentration there was an impact on nitrification in the copper system that persisted after the cessation of chlorite addition. McGuire et al. (1999) mentions that chlorite did not inhibit nitrification in one system, which according to the author may be due to the presence of higher ammonia (1.4 mg/L). Karim and LeChevallier (2006) also reported that chlorite was unable to hinder nitrification. All these studies were done with low doses of chlorite $(0.2-1.0 \mathrm{ppm})$ and their flow pattern, water quality and bacterial population/biofilm characteristics may be significantly different from this project. Another possible explanation is that chlorite inhibits the activity of Nitrosomonas europaea and Nitrobacter winogradski (Hynes and Knowles, 1983), but may be inactive toward other groups of $\mathrm{AOB}$ and NOB that may be predominant in the reactors.

The planktonic and biofilm heterotrophic populations were unaffected by chlorite exposure. The trend in heterotrophic numbers supports previous work by Gagnon et al. (2005) where chlorite at $0.1-0.25 \mathrm{ppm}$ was ineffective in inactivating heterotrophic bacteria. Similar to HPC, AOB values did not show any effect due to chlorite exposure. The planktonic NOB population remained unchanged for all concentrations of chlorite except at $20 \mathrm{ppm}$, when they could not be detected. NOB were also not detected in the copper reactor's biofilm at the end of exposure period to the high chlorite concentration. Hynes and Knowles (1983) reported that pure cultures of AOB (N. europaea) and NOB (N. winogradski) were inhibited by chlorite, and that the $\mathrm{AOB}$ are 50 times more sensitive to chlorite inhibition than NOB. In our experiments it appeared that the NOB were more sensitive than the AOB. Again this may be due to the differences in experimental setup, pure cultures vs environmental biofilm, water quality and other factors. It is also possible that the methods used in this work did not enumerate all of the potential nitrifying organisms in the reactors.

A potential impact of chlorite on copper plumbing could be an increased release of copper into the water. As chlorite $\left(\mathrm{ClO}_{2}^{-2}\right)$ could be transformed to chlorine dioxide $\left(\mathrm{ClO}_{2}\right)$ in an acidic environment (Gates, 1989) that could created by oxidation of ammonia during nitrification by biofilm on the surfaces, copper corrosion could increase due to the oxidative nature of chlorine dioxide. Therefore, there could be an unintended result of elevated copper release when chlorite is applied, and this was seen in these experiments. For this reason, and because chlorite is a regulated compound, the utilities should carefully evaluate chlorite before implementing it as a nitrification control strategy.

\subsection{Chloramine}

According to a survey by Seidel et al. (2005), optimizing the chlorine to ammonia ratio is the most common nitrification control technique. The chlorine to ammonia- $\mathrm{N}$ weight ratio used to form monochloramine typically varies from 3:1 to 5:1 (Wilczak, 2006). Several studies in full scale chloraminated systems have determined that a minimum 2-3 $\mathrm{mg} \mathrm{Cl} / \mathrm{L}$ chloramine residual should be maintained to prevent nitrification (Wolfe et al., 1990; Lieu et al., 1993; Kirmeyer et al., 1995; Odell et al., 1996; Harrington et al., 2002). A combination of chloramines does and optimizing the chlorine to ammonia ratio has been shown to be the easiest and most cost-effective way to control/prevent nitrification (Lieu et al., 1993).

The results of this work can be compared to several studies where the chlorine to ammonia ratio has been measured in pilot and full scale systems and related to nitrification. McGuire et al. (2004) showed that nitrification occurred in a pilot system where chloramine was applied at a 3:1 ratio. Similarly, for two covered finished water reservoirs in southern California which were initially chloraminated at a 3:1 ratio, nitrification was significantly reduced after raising the ratio to $5: 1$ (Wolfe et al., 1988). A Florida utility rarely experienced nitrification when the combined chlorine residual was above $1 \mathrm{mg} / \mathrm{L}$ at a chlorine to ammonia ratio of 5:1 (Liu et al., 2005). A study done by Karim and LeChevallier (2006) showed that monochloramine applied at a 3:1 ratio was not able to control nitrification, but it was effective at a 5:1 ratio.

Based on the above information, the impact of an incremental increase in the chlorine to ammonia ratio on nitrification was tested. The intent was to test situations in (1) a system where chloramine residual was regained and/or (2) households downstream of booster chlorination that was used to recreate chloramines from free ammonia (Wolfe and Lieu, 2001; Wilczak, 2006). At the starting ratio of 0.5:1, about $0.35 \mathrm{mg} / \mathrm{L}$ of total chlorine was present. This was chosen because Holt et al. (1995) showed reduction of nitrification at total chlorine concentrations of more than $0.3 \mathrm{mg} / \mathrm{L}$. However, at an $8 \mathrm{~h}$ stagnation time, this low ratio did not have an impact on nitrification and organisms responsible for nitrification could be found in the bulk water and biofilm. Very minor transient impacts were seen with increasing ratios of 1:1, 1.5:1, and 2:1. There are several possible explanations for these results. Nitrifying bacteria form protective layers (slime layer or capsules) mainly composed of polysaccharides (Prosser, 1986) as a defensive mechanism against unfavorable environmental conditions such as low $\mathrm{pH}$. These capsules protect organisms so that they are more resistant to disinfectants (Stewart and Olson, 1996). Cunliffe (1991) detected nitrifiers in $64 \%$ of the samples collected in South Australia and of them $20.7 \%$ contained more than $5.0 \mathrm{mg} \mathrm{Cl} / \mathrm{L}$ of monochloramine. The author hypothesized that as the nitrifiers grow in aggregates or in biofilm attached to the surface, they remain unaffected by disinfectant and the nitrifiers detected in samples containing high chloramine residual may have been detached shortly before or during the sampling 
period. Higher AOB have been detected in biofilm than water in the Metropolitan Water District of Southern California distribution system (Stewart and Lieu, 1997). Regan (2001) postulated on the protective mechanism of biofilms. Monochloramine is mass transport limited in biofilm, so bacteria inside the biofilm are not exposed to the disinfectant. Another protective mechanism may be the relative ratio of growth vs disinfection. Harrington et al. (2003) stated that if AOB growth rate driven by ammonia concentration exceeds the $A O B$ inactivation rate by monochloramine, then theoretically $\mathrm{AOB}$ can grow in the presence of monochloramine. Fleming et al. (2005) proposed nitrification potential curves based on the relative concentration of chlorine (biocide) and free ammonia (food). According to them the threshold chlorine value is 1.6, above which nitrification would be prevented, without any influence from free ammonia concentration. At chlorine concentrations below 1.6, the nitrification potential depends on the ratio of chlorine and free ammonia.

Only when the $5: 1 \mathrm{Cl}_{2}$ to $\mathrm{NH}_{3}-\mathrm{N}$ ratio was reached was there a consistent reduction of nitrification during the $8 \mathrm{~h}$ of stagnation, and the affect of this ratio agrees with results from Karim and LeChevallier (2006) and Lieu et al. (1993). Likewise, in work by Harrington et al. (2002), nitrification did not occur when the total chlorine concentrations were more than $2.2 \mathrm{mg} / \mathrm{L}$ and the biocide to food ratio was $1.9 \mathrm{mg} \mathrm{Cl} / 2 / \mathrm{mg}$ of $\mathrm{N}$ or more. The most pronounced effect was on the PVC reactor, which is in contrast to the chlorite effect which was most obvious on the copper reactor. Interestingly, the HPC numbers in the biofilm on the copper surfaces were lower than those of the AOB, suggesting that the disinfectant had greater activity on the HPC than the nitrifiers. No planktonic NOB were detected in monochloramine exposed reactors at the 5:1 ratio and they were also not detected in the biofilm of the copper reactor. A possible explanation is that the NOB were more vulnerable to disinfection than the AOB (Wolfe and Lieu, 2001).

These results also support observations that once nitrification starts in full scale systems, higher levels of chloramine may not be an effective control method. Skadsen (1993) reported that a chloramine dose of $8 \mathrm{mg} \mathrm{Cl}_{2} / \mathrm{L}$ was not effective in controlling nitrification in the Ann Arbor, Michigan distribution system. This may be due to the fact that nitrite can degrade chloramine residuals before it can inactivate the nitrifying bacteria (Wolfe et al., 1988; Kirmeyer et al., 1995; Odell et al., 1996). Also, maintaining monochloramine at a high ratio close to 5:1 in full scale systems is not always easy, and is sometimes associated with dicholoramine formation, and taste/odor problems and higher DBP formation (Skadsen and Cohen, 2006).

This project also provides some insight on effect of chloramine on copper corrosion. It has been found that chloramine increased copper corrosion (Ingleson et al., 1949). Enhanced copper solubility during periods of chloramination with excess ammonia present was observed for Champaign IL tap water (AwwaRF, 1990). Ammonia has a strong complexation constant for cupric ion (Schock et al., 1995). On the other hand, according to MacQuarrie et al. (1997) and Rahman et al. (2007), application of monochloramine results in a decrease in copper pipe corrosion. Current results found higher total and dissolved copper concentrations in the reactors where the disinfectant was added.

\subsection{Copper vs PVC surfaces}

Copper and PVC were chosen because of their use in plumbing systems and also because of the potential antimicrobial effect of copper vs PVC. One could also hypothesize that copper materials may be more prone to nitrification in chloraminated systems because monochloramine can rapidly decay through reactions with a copper plumbing system (Edwards and Nguyen, 2005), therefore providing more free ammonia for nitrification. Therefore, pipe material could significantly influence the nitrification process.

In the conditioned control reactors with no added chlorite or chlorine, there was no difference in ammonia utilization between the two surfaces, and the HPC, AOB and NOB numbers were similar. The lack of efficacy of copper against these organisms was supported by the experiments where copper was added to the PVC reactor and no decrease in nitrification was seen. In the presence of chorite or combined chlorine, there were some differences between the two systems. In the case of chlorite, nitrification in the copper system was affected to a greater extent with a loss of nitrification at the highest concentration $(20 \mathrm{ppm})$ and an extended recovery time after chlorite addition ceased. This could be because of the production of chlorine dioxide (Gates, 1989) on the metal surface. However, in the presence of combined chlorine, the PVC system was more greatly impacted; nitrification ceased and it required nearly six weeks for recovery. In the copper reactor, there was never a complete loss of nitrification, and complete nitrification was again attained only three weeks after chlorine addition stopped. This suggests that the mechanism of chloramine decay on the copper surface, as reported by Edwards and Nguyen (2005), could be at play.

\subsection{Relationship between HPC and nitrification}

Some research has shown that there is a correlation between HPC values and nitrification in water systems with HPC increasing when nitrification occurs. Wolfe et al. (1990) reported that HPC and AOB population were highly correlated in distribution system water, and that this may be explained due to the dependence of HPC on AOB for carbon fixation. However, other researchers reported that the relationship is very site specific (Donnelly and Giani, 2005), likely because HPC can grow in response to other available organics and their numbers are also affected by residual disinfectant. Throughout these experiments there was no consistent relationship between HPC and AOB/NOB MPN values. This may be due to the presence of humic substances in the reactors.

\section{Conclusions}

- Copper surfaces or copper added to reactors at concentrations up to $1.3 \mathrm{ppm}$ within a $\mathrm{pH}$ range of $6.6-8.15 \mathrm{did}$ not inhibit nitrification.

- Chlorite was effective at inhibiting nitrification only at an unrealistic dose (20 ppm), on copper surfaces. There was limited, transient control on reactors with PVC surfaces at 20 ppm chlorite. 
- Chloramine at a $\mathrm{Cl}_{2}$ to $\mathrm{NH}_{3}-\mathrm{N}$ ratio of 5:1 managed nitrification in the copper reactor and was able to control it in the PVC system.

- The addition of chlorite and chloramines may increase copper corrosion.

- No correlation between HPC and AOB/NOB was found.

- Time to recovery after cessation of addition of chlorite and chloramine varied but did occur, suggesting that nitrification in premises plumbing is a robust process.

\section{Acknowledgments}

This material is based upon work supported by the National Science Foundation under Grant No. 0329474. Any opinions, findings, and conclusions or recommendations expressed in this material are those of the authors and do not necessarily reflect the views of the National Science Foundation. The authors thank the MUSES team funded by this grant and led by Dr. Andrea Dietrich at Virginia Tech for their insights, with special appreciation to Dr. Marc Edwards for his assistance. The authors also acknowledge John Neuman and Daniel Swanson for their help in the laboratory.

\section{R E F E R E N C E S}

Alexander, M., Clark, F.E., 1965. Nitrifying bacteria. In: Black, C.A. (Ed.), Methods of Soil Analysis. American Society of Agronomy, Madison, WI, pp. 1477-1483. Part 2.

Alt, E.R., Sternlieb, I., Goldfischer, S., 1990. The cyto-pathology of metal overload. International Review of Experimental Pathology 31, 165-188.

Artz, R.R.E., Killham, K., 2002. Survival of Escherichia coli O157:H7 in private drinking water wells: influences of protozoan grazing and elevated copper concentrations. FEMS Microbiology Letters 216 (1), 117-122.

American Water Works Association Research Foundation, 1990. Lead Control Strategies. AWWA Research Foundation and AWWA, Denver, CO.

Braam, F., Klapwijk, A., 1981. Effect of copper on nitrification in activated sludge. Water Research 15 (9), 1093-1098.

Clescerl, L.S., Greenberg, A.E., Eaton, A.E. (Eds.), 1995. Standard Methods for Examination of Water \& Wastewater, nineteenth ed. American Public Health Association.

Crecelius, W.A., Hardy, J.T., Gibson, C.I., Schmid, T.R.L., Apts, C.W., Curtisen, J.M., Joyce, S.P., 1982. Copper bioavailability to marine bivalves and shrimps: relationship to cupric ion activity. Marine Environmental Research 6 (1), 13-26.

Cunliffe, D.A., 1991. Bacterial nitrification in chloraminated water supplies. Applied and Environmental Microbiology 57 (11), 3399-3402.

Dodge, E.E., Theis, T.L., 1979. Effect of chemical speciation on the uptake of copper by Chironomus tentans. Environmental Science Technology 13 (10), 1287-1288.

Donnelly, M., Giani, R., 2005. Developing nitrification control limits from distribution system data. In: Proceedings of American Water Works Association Water Quality Conference, Denver CO.

Edwards, M., Nguyen, C., 2005. Chemistry of rapid chloramine decay in water contacting copper plumbing. In: Proceedings of
American Water Works Association Water Quality Technology Conference, Quebec City, Canada.

Edwards, M., Schock, M.R., Meyer, T.E., 1996. Alkalinity, pH and copper corrosion by-product release. Journal of American Water Works Association 88 (3), 81-88.

Fleming, K.K., Harrington, G.W., Noguera, D.R., 2005. Nitrification potential curves: a new strategy for nitrification prevention. Journal of American Water Works Association 97 (8), 90-99.

Gagnon, G.A., Rand, J.L., O'Leary, K.C., Rygel, A.C., Chauret, C., Andrews, R.C., 2005. Disinfectant efficacy of chlorite and chlorine dioxide in drinking water biofilm. Water Research 39 (9), 1809-1817.

Gates, D., 1989. Chlorine dioxide generation technology and mythology. In: Proceedings of AWWA Water Quality Conference, Denver CO.

Geesey, G.G., Jang, L., 1989. Interactions between metal ions and capsular polymers. In: Beveridge, T.J., Doyle, R.J. (Eds.), Metal Ions and Bacteria. Wiley \& Sons, New York, pp. 325-357.

Goeres, M.D., Loetterle, L.R., Hamilton, M.A., Murga, R., Kirby, D. W., Donlan, R.M., 2005. Statistical assessment of a laboratory method for growing biofilms. Microbiology 151 (3), 757-762.

Harrington, G.W., Noguera, D.R., Kandou, A.I., Vanhoven, D.J., 2002. Pilot-scale evolution of nitrification control strategies. Journal of American Water Works Association 94 (11), 78-89.

Harrington, G.W., Noguera, D.R., Bone, C.C., Kandou, A.I., Oldenburg, P.S., Regan, J.M., Hoven, D.V., 2003. Ammonia from Chloramine Decay: Effect on Distribution System Nitrification. AWWA Research Foundation, Denver, CO.

Holt, D., Todd. R.D., Delanoue, A., Colborne, J.S., 1995. A study of nitrite formation and control in chloraminated distribution systems. In: Proceedings of American Water Works Association Water Quality Technology Conference, Denver, CO.

Hu, Z., Chandran, K., Grasso, D., Smets, B.F., 2003. Impact of metal sorption and internalization on nitrification inhibition. Environmental Science Technology 37 (4), 728-734.

Hynes, R.K., Knowles, R., 1983. Inhibition of chemoautotrophic nitrification by sodium chlorate and sodium chlorite: a reexamination. Applied and Environmental Microbiology 45 (4), 1178-1182.

Ingleson, H., Sage, A.M., Wilkinson, R., 1949. Effect of chlorination of drinking water on brass fittings. Journal of Industrial Water Engineering 3 (1), 81-91.

Karim, M.R., LeChevallier, M.W., 2006. Alternative treatment for nitrification control in chloraminating utilities. In: Proceedings of the AWWA Annual Conference, San Antonio TX

Kim, B.R., Andersson, J.E., Mueller, S.A., Gaines, W.A., Kendall, A. M., 2002. Literature review-efficacy of various disinfectants against Legionella in water systems. Water Research 36 (18), 4433-4444.

Kim, K.T., Kim, I.S., Hwang, S.H., Kim, S.D., 2006. Estimating the combined effect of copper and phenol to nitrifying bacteria in wastewater treatment plants. Water Research 40 (3), 561-568.

Kindaichi, T., Kawano, Y., Ito, T., Satoh, H., Okabe, S., 2006. Population dynamics and in situ kinetics of nitrifying bacteria in autotrophic nitrifying biofilms as determined by real-time quantitative PCR. Biotechnology and Bioengineering 94 (6), $1111-1121$.

Kirmeyer, G.J., Odell, L.H., Jacangelo, J.G., Wilczak, A., Wolfe, R.L., 1995. Nitrification Occurrence and Control in Chloraminated Water Systems. AWWARF and AWWA, Denver CO.

LeChevallier, M.W., Cawthon, C.D., Lee, R.G., 1988. Inactivation of biofilm bacteria. Applied and Environvironmental Microbiology 54 (10), 2492-2499.

Lee, Y.W., Ong, S.K., Sato, C., 1997. Effect of heavy metals on nitrifying bacteria. Water Science and Technology 36 (12), 69-74.

Lehtola, M.J., Miettinen, I.T., Kienanen, M.M., Kekki, T.K., Laine, O., Hirvonen, A., Vartiainen, T., Martikainen, P.J., 2004. Microbiology, chemistry and biofilm development in a pilot 
drinking water distribution system with copper and plastic pipes. Water Research 38 (17), 3769-3779.

Lieu, N.I., Wolfe, R.L., Means, E.G., 1993. Optimizing chloramine disinfection for control of nitrification. Journal of American Water Works Association 85 (2), 84-90.

Liu, S., Taylor, J.S., Randall, A.A., Dietz, J.D., 2005. Nitrification modeling in chloraminated distribution systems. Journal of American Water Works Association 97, 98-108.

Loveless, J.E., Painter, H.A., 1968. The influence of metal ion concentration and $\mathrm{pH}$ value on the growth of a Nitrosomonas strain isolated from activated sludge. Journal of General Microbiology 52 (1), 1-14.

MacQuarrie, D.M., Mavinic, D.S., Neden, D.G., 1997. Greater vancouver water district drinking water corrosion inhibitor testing. Canadian Journal of Civil Engineering 24 (1), 34-52.

Martin, G., Richard, Y., 1982. Elements of inhibition of nitrifying bacteria. Water Science and Technology 14 (6-7), 781-794.

McGuire, M., Lieu, J.N., Pearthree, M., 1999. Using chlorite ion to control nitrification. Journal of American Water Works Association 91 (10), 52-62.

McGuire, M.J., Pearthree, M., Blute, N.K., Arnod, K.F., 2004. Tucson nitrification control pilot study: a significant advance in the state of the art of implementing chloramines in a desert environment. Arizona Water and Pollution Control Association Annual Conference.

McGuire, M.J., Pearthree, M.S., Blute, N.K., Arnold, K.F., Hoogerwerf, T., 2006. Nitrification control by chlorite ion at pilot scale. Journal of American Water Works Association 98 (1), 95-105.

McGuire, M.J., Wu, X., Blute, N.K., Askenaizer, D., Qin, G., 2009. Prevention of nitrification using chlorite ion: results of a demonstration project in Glendale, Calif. Journal of American Water Works Association 101 (10), 47-59.

Meiklejohn, J., 1950. The isolation of Nitrosomonas europaea in pure culture. Journal of General Microbiology 4 (2), 185-191.

National Research Council, 2006. Water Science and Technology Board, Science and Technology Board. Drinking Water Distribution Systems: Assessing and Reducing Risks. The National Academies Press, Washington D.C.

National Sanitation Foundation, 2008. http://www.nsf.org/ consumer/plumbing/index.asp (accessed 18.06.08.).

Odell, L.H., Kirkrmeyer, G.J., Wilczak, A., Jacangelo, J.G., Marcinko, J.P., Wolfe, R.L., 1996. Controlling nitrification in chloraminated systems. Journal of American Water Works Association 88 (7), 86-98.

Okabe, S., Kinadaichi, T., Itoh, T., 2005. Fate of ${ }^{14} \mathrm{C}$-labeled microbial products derived from nitrifying bacteria in autotrophic nitrifying biofilms. Applied and Environmental Microbiology 71 (7), 3987-3994.

Oskarsson, A., Norrgren, L., 1998. Copper pipes as a source of copper exposure in man and environment. Environmental Reviews 6, 139-150.

Prosser, J.I., 1986. Experimental and theoretical models of nitrification. In: Prosser, J.I. (Ed.), Nitrification. IRL Press, Oxford, England, pp. 74-75.

Rahman, S., McDonald, B.C., Gagnon, G.A., 2007. Impact of secondary disinfectants on copper corrosion under stagnation conditions. Journal of Environmental Engineering 133 (2), 180-185.

Regan, J. M., 2001. Microbial Ecology of Nitrification in Chloraminated Drinking Water Distribution Systems, Ph.D Dissertation, University of Wisconsin, Madison, Wisconsin.

Rittmann, B.E., Regan, J.M., Stahl, D.A., 1994. Nitrification as a source of soluble organic substrate in biological treatment. Water Science and Technology 30 (6), 1-8.

Rowe, R., Todd, R., Waide, J., 1977. Microtechnique for most probable number analysis. Applied and Environmental Microbiology 33 (3), 675-680.
Sarathy, V., Allen, H.E., 2005. Copper complexation by dissolved organic matter from surface water and wastewater effluent. Ecotoxicology and Environmental Safety 62, 337-344.

Sato, C., Leung, S.W., Schnoor, J.L., 1988. Toxic response of Nitrosomonas europaea to copper in inorganic media and wastewater. Water Research 22 (9), 1117-1127.

Schock, M., Lytle, D., Clement, J., 1995. Effect of pH, DIC, orthophosphate and sulfate on drinking water cuprosolvency. US EPA Report/600/R-95/085 June 1995.

Schramm, A., Larsen, L.H., Revsbech, N.P., Ramsing, N.B., Amman, R., Schleifer, K.H., 1996. Structure and function of a nitrifying biofilm as determined by in situ hybridization and the use of microelectrodes. Applied and Environmental Microbiology 62 (12), 4641-4647.

Seidel, C.J., McGuire, M.J., Summers, S., Via, S., 2005. Have utilities switched to chloramines? Journal of American Water Works Association 97 (10), 87-97.

Skadsen, J., 1993. Nitrification in a distribution system. Journal of American Water Works Association 85 (7), 95-103.

Skadsen, J., Cohen, Y.K., 2006. Fundamentals and Control of Nitrification in Chloraminated Drinking Water Distribution System. AWWA Manual M56. American Water Works Association, Denver, CO.

Skinner, F.A., Walker, N., 1961. Growth of Nitrosomonas europaea in batch and continuous culture. Archives of Microbiology 38, 339-349.

Stewart, M.H., Olson, B.H., 1996. Bacterial resistance to potable water disinfectants. In: Hurst, C.J. (Ed.), Modeling Disease Transmission and its Prevention by Disinfection. Cambridge University Press, Cambridge, England, pp. 140-192.

Stewart, M.H., Lieu, N.I., 1997. Nitrification in chloraminated drinking water and its association with biofilms. In: Proceedings of the AWWA Water Quality Technology Conference, Denver, CO.

Teitzel, G.M., Parsek, M.K., 2003. Heavy metal resistance of biofilm and planktonic Pseudomonas aeruginosa. Applied and Environmental Microbiology 69 (4), 2313-2320.

Thurman, R.B., Gerba, C.P., 1989. The molecular mechanisms of copper and silver ion disinfection of bacteria and viruses. CRC Critical Review-Environmental Control 18 (4), 295-315.

Tomlinson, T.G., Boon, A.G., Trotman, C.N.A., 1966. Inhibition of nitrification in the activated sludge process of sewage disposal. Journal of Applied Bacteriology 29 (2), 266-291.

USEPA, 1993. Method for the Determination of Inorganic Substances in Environmental Samples. EPA/600/R-93/100 Washington D.C.

USEPA, 2000. Microbial/Disinfection Byproducts (M-DBP) Federal Advisory Committee: Stage $2 \mathrm{M}$-DBP Agreement in Principle. EPA, Washington, D.C.

Wahman, D.G., Wulfeck-Kleier, K.A., Pressman, J.G., 2009. Monochloramine disinfection kinetics of Nitrosomonas europaea by propidium monoazide quantitative PCR and live/ dead BacLight methods. Applied and Environmental Microbiology 75 (17), 5555-5562.

Wilczak, A., 2006. Overview of causes and control of nitrification in water distribution systems. Chapter 4. In: Kosyra, M.K. (Ed.), Fundamentals and Control of Nitrification in Chloraminated Drinking Water Distribution Systems, AWWA Manual M56. American Water Works Association, Denver, CO.

Wilczak, A., Jacangelo, J.G., Marcinko, J.P., Odell, L.H., Kirmeyer, G. J., Wolfe, R.L., 1996. Occurrence of nitrification in chloraminated distribution systems. Journal of American Water Works Association 88 (7), 74-85.

Wolfe, R.L., Lieu, N.I., 2001. Nitrifying bacteria in drinking water. In: Bitton, G. (Ed.), Encyclopedia of Environmental Microbiology. John Wiley and Sons, New York, NY. 
Wolfe, R.L., Means III, E.G., Davis, M.K., Barrett, S.E., 1988. Biological nitrification in covered reservoirs containing chloraminated water. Journal of American Water Works Association 80 (9), 109-114.

Wolfe, R.L., Lieu, N.I., Izaguirre, G., Means, E.G., 1990. Ammoniaoxidizing bacteria in chloraminated distribution systems: seasonal occurrence, distribution and disinfection resistance. Applied and Environmental Microbiology 56 (2), 451-462.
Zhang, Y., Edwards, M., 2005. Water chemistry and growth of nitrifying bacteria in drinking water distribution systems. In: Proceedings of the American Water Works Association Water Quality Technology Conference, Denver, CO.

Zhang, Y., Griffin, A., Rahman, M., Camper, A., Baribeau, H., Edwards, M., 2009. Lead contamination of potable water due to nitrification. Environmental Science and Technology 43 (6), 1890-1895. 